\title{
Particularities of English for Specific Purposes and Development of Intercultural Competence
}

\section{[Specifika odbornej anglictiny a rozvijanie interkulturnej kompetencie]}

\author{
Anna Zelenkova
}

\section{DOI: 10.18355/XL.2015.08.01.36-49}

\begin{abstract}
Abstrakt
Výučba odborných cudzích jazykov na nefilologických fakultách pripravuje absolventov na komunikáciu v medzinárodnom študijnom a pracovnom prostredí, kde interkultúrna kompetencia zohráva dôležitú rolu. Uvedená štúdia skúma faktory, ktoré ovplyvňujú súčasné zameranie výučby odborných cudzích jazykov, definuje jej priority a špecifiká a predstavuje komplexnost' jej výučby $\mathrm{v}$ interdisciplinárnych súvislostiach. Na príklade vybraných indikátorov odbornej angličtiny zdôvodňuje nutnost' interkultúrneho smerovania jej výučby.

Klúčové slová

Odborný cudzí jazyk, odborná angličtina, akademická angličtina, interkultúrna kompetencia, didaktika cudzích jazykov
\end{abstract}

\section{Úvod}

Výučba odborných cudzích jazykov na nefilologických fakultách sa orientuje na študijný odbor alebo študijný program $v$ danej vedeckej disciplíne a kladie si za ciel' pripravit' absolventa na bezproblémové fungovanie $\mathrm{v}$ medzinárodnom študijnom či pracovnom prostredí. Odborné cudzie jazyky sa vyučujú v ekonomických, technických, medicínskych, pedagogických a iných humanitných a prírodovedných disciplínach. V súvislosti s internacionalizáciou ekonomického, kultúrneho a spoločenského života a s tým súvisiacim interkultúrnym charakterom komunikačných procesov sa do popredia dostávajú otázky interkultúrnej kompetencie. O nutnosti rozvíjania interkultúrnej kompetencie vo výučbe odborných cudzích jazykov hovoríme aj v súvislosti s chápaním súčasného modelu komunikatívnej kompetencie, ktorý predstavuje nielen poznanie a ovládanie jazyka, ale zahŕňa aj „komponent kultúrneho poznania a uvedomenia“ (Rada Europy, 2001: 26, 104). Podla Kollarovej (2013: 5) sa cudzí jazyk v ponímaní dnešnej didaktiky „stáva nie ciel'om, ale prostriedkom - na medzikultúrne dorozumenie, komunikáciu medzi kultúrne odlišnými účastníkmi.“ Tandlichová zdôrazňuje uvedomenie si jednoty jazyka a kultúry a kontext sociokultúrneho správania sa partnerov v komunikácii. Podl'a nej, ,ak chceme byt' úspešní v komunikácii s cudzincom, čo nemusí byt' vždy rodený hovoriaci, treba si neustále uvedomovat', že každý je súčastou svojho kultúrneho kontextu, ktorý si prináša do kontaktu s ostatnými, napriek tomu, že partneri používajú spoločný cudzí jazyk, napríklad angličtinu." (Tandlichova, 2010: 9-10). V odbornej angličtine na vysokej škole (napríklad ekonomického zamerania) je tento fakt významnejší o to viac, že študenti sú pripravovaní na komunikáciu s príslušníkmi iných kultúr v rámci medzinárodných obchodných kontaktov. Správne použitie jazyka prispieva kefektívnosti komunikácie, nadviazaniu a udržaniu obchodných kontaktov, zatial' čo situačne a kultúrne nesprávne použitie jazyka, ignorovanie nuáns $\mathrm{v}$ jazyku vyplývajúcich $\mathrm{z}$ iného kultúrneho zázemia môže viest' k zlyhaniu spolupráce alebo kontraktu.

Vo výučbe cudzích jazykov sa predpokladá, že štúdium cudzieho jazyka automaticky sprostredkúva interkultúrnu kompetenciu, ked’že jazyk je nositel’om určitých znakov kultúry. Doterajšia prax však ukazuje, že didaktika operuje s pomerne 
úzkou koncepciou vzt’ahu jazyka a kultúry a nemá celkom jasno vo veci osvojovania si interkultúrnej kompetencie (Lazar, 2013). Súhlasíme s Kramschovou (1998: 12), ktorá tvrdí, že jazyk sa stále vyučuje ako pevný systém formálnych štruktúr a univerzálnych jazykových funkcií. Kultúra tvorí len pridaný element, ale to až do takej miery, že len podporuje a upevňuje, nie zmierňuje, tradičné hranice medzi ponímaním seba a iných. Učitelia teda učia jazyk a kultúru, nie jazyk ako kultúru. Uvedená autorka navrhuje taký rámec pre výučbu kultúry, ktorý by upúštal od tradičnej dichotómie medzi všeobecným a špecifickým (odlišným). Výučba jazyka by mala tvorit' platformu pre dialóg a spoločné úsilie zmiernenia rozdielov. Aby sme mohli efektívne komunikovat', musíme jazyk nielen dobre ovládat', ale vediet' ho použit' vhodne podl'a situácie, daného rečového kontextu a s ohl'adom na kultúrne prostredie, sociokultúrny kontext (Byram - Fleming, 1998).

\section{Ciel', materiál a metodika}

Ciel'om tejto teoretickej štúdie je predstavit' odbornú angličtinu a jej špecifiká $\mathrm{v}$ súvislosti s rozvíjaním interkultúrnej kompetencie. Náčrtom stručného vývoja jej výučby v kontexte slovenského vysokoškolského vzdelávania poukážeme na rozdiely v prístupoch $\mathrm{k}$ jej výučbe, definujeme faktory, ktoré ovplyvňujú jej dnešné zameranie $\mathrm{z}$ pohl'adu potrieb študujúcich, výučbových a učebných ciel'ov, a to v akademickej i profesijnej oblasti. Východiskom skúmania sú teoretické poznatky súčasnej didaktiky cudzích jazykov a d'alších príbuzných vedných disciplín, ktoré majú vplyv na obsah a zameranie výučby. Teoretickú bázu založenú na domácich a zahraničných vedeckých zdrojoch doplńajú zdôvodnenia niektorých prístupov overených akčným výskumom v pedagogickej praxi autorky.

\section{Odborná angličtina a interkultúrna kompetencia}

Postavenie interkultúrnej kompetencie ako ciel’a výučby cudzích jazykov ilustrujeme na príklade odbornej angličtiny, ktorú mnohí autori nazývajú angličtina pre špecifické účely (doslovný preklad anglického termínu English for specific purposes, d’alej ESP). Prikláňame sa k názoru, že termín odborná angličtina je slovenskejší a dostatočne vystihuje podstatu ESP. Odborná angličtina zaznamenala vel'ký rozmach v 90 . rokoch 20 . storočia, pretože angličtina sa začala používat' ako lingua franca na komunikáciu v najrôznejších profesijných oblastiach.

Vo vysokoškolskom systéme vzdelávania sa odborná angličtina vyučuje na nefilologických fakultách a obsah jej výučby je odlišný od výučby cudzích jazykov na filologických/filozofických fakultách pripravujúcich učitel’ov a tlmočníkov. Táto zahŕňa kultúrny komponent celkom prirodzene vo forme predmetu zameraného na kultúru krajiny (krajín) ciel'ového jazyka. Toto štúdium kultúry sa spája predovšetkým so štúdiom literatúry, histórie, spoločenského a politického systému a iných faktografických informácií o danej krajine, ktoré sa často označujú za reálie danej krajiny. Podl'a Kačmárovej (2012, online) Chang poukázal na to, že štúdium kultúry bolo pôvodne súčast'ou štúdia literatúry, až kým Williams a Hoggart nepoukázali na vzájomný vplyv jazyka a kultúry. Tento informačný krajinovedný blok sa pokladá za samozrejmú súčast' štúdia cudzích jazykov, rovnako ako osvojovanie si s idiomatickýh jednotiek, kolokvializmov a metaforických výrazov, ktoré je t’ažké interpretovat' a ktoré sú tiež súčast'ou jazykovej kultúrnej kompetencie.

Avšak interkultúrna komunikácia je niečo komplexnejšie, než sebaisté použitie kolokácií a iných jazykových zvláštností; predstavuje množstvo výziev v podobe komunikačných situácií, na ktoré treba vediet' adekvátne reagovat' (Lustig Koester, 2009: 28-32).

Z tohto faktu vyplývajú výzvy pre výučbu odborných cudzích jazykov a miesto interkultúrnej kompetencie medzi ciel'ovými komunikačnými 
kompetenciami. Absolvent uvedených odborov by mal byt' pripravený komunikovat' v kultúrne odlišnom prostredí s odborníkmi vo svojej profesijnej oblasti, zvládnut' situačné použitie jazyka a odlišnosti v komunikácii na rôznych úrovniach a v rôznych formách - písomnej i ústnej, verbálnej i neverbálnej. Od študenta sa očakáva spôsobilost' pracovat' $\mathrm{s}$ informáciami, ktoré nazhromaždila jeho socioprofesijná skupina - jazykové spoločenstvo, či skupina diskurzu (Šimkova (2011: 323). Socioprofesijná komunikácia je špecifická tým, že jej účastníci disponujú spoločnými poznatkami a vedomost'ami v mimojazykovej oblasti, t. j. vo sfére vlastnej špecializácie, vlastného odboru, a do komunikácie vnášajú svoje osobné profesijné skúsenosti. Je nutné, aby ovládali určité zvyklosti a normy správania, ako aj využívali špecifické prostriedky dorozumievania - verbálne i neverbálne. Používanie cudzieho jazyka pri štúdiu svojho odboru alebo pri výkone práce tak celkom súvisí s osobitným komunikačným kontextom, ktorý sa podstatne odlišuje od používania jazyka vo všeobecnom kontexte. Sledovanie rozličných ciel'ov v komunikácii, rôznorodost' rečových činností v komunikačných situáciách ako aj značné množstvo samotných komunikačných situácií, ktoré môžu nastat' v tomto kontexte, ovplyvňujú výber jazykových prostriedkov a ich usporiadanie v prehovore (texte, komunikáte).

Nároky kladené na odbornú komunikáciu majú priamy dopad na didaktiku cudzích jazykov. Tieto nároky ovplyvňujú spôsoby a prostriedky, akými sa dnes cudzí jazyk učí a osvojuje. V súvislosti s takto zameranou odbornou jazykovou prípravou možno stanovit' niekol'ko úrovní podl'a sledovaných ciel'ov a obsahu výučby, ako i ciel'ových skupín, na ktoré sa jazyková príprava zameriava. V prípade štúdia cudzích jazykov na nefilologických fakultách možno hovorit' o dvojakom zameraní odbornej jazykovej prípravy:

a) štúdium cudzieho jazyka na akademické, resp. študijné účely (Achugar, Carpenter, 2014) - využitie jazyka v štúdiu odboru v štúdiu v zahraničí, v mobilitných programoch Európskej únie). Donohue, Erling (2012) výskumom potvrdili, že existuje korelácia medzi akademickým výkonom študenta a úrovňou ovládania akademickej angličtiny;

b) štúdium cudzieho jazyka na profesijné účely (využitie v budúcej profesii, $v$ danej profesijnej sfére). Toto zameranie odbornej angličtiny znázorňuje schéma 1.

ODBORNÁ ANGLIČTINA

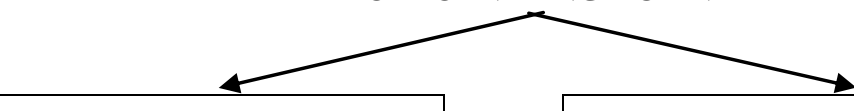

Angličtina na profesijné účely

\begin{tabular}{|l|}
\hline \multicolumn{1}{|c|}{ Angličtina na akademické účely } \\
\hline 1. Angličtina na odborné akademické \\
účely v štúdiu ekonómie, techniky, \\
medicíny, práva, a i. \\
2. Angličtina na všeobecné \\
akademické účely \\
počúvanie a robenie si poznámok, \\
písanie akademických textov - abstrakt, \\
zhrnutie, citovanie, seminárne \\
a záverečné práce, diskutovanie, \\
argumentovanie, práca so zdrojmi, \\
akademický jazyk, výber vhodných \\
jazykových prostriedkov, a podobne. \\
\hline
\end{tabular}

Schéma 1 Zameranie odbornej angličtiny

(spracované podl'a Dudley-Evans a St John (1998) a Jordan (1997). 
Dôraz na akademickú oblast' vyplýva z internacionalizácie vzdelávania, zvýšenej spolupráce univerzít a mobility študentov, vedcov i učitel’ov, ktoré umožňujú programy Európskej únie. Študenti už môžu študovat' svoj odbor aj na zahraničných univerzitách a k tomu by mali ovládat' zručnosti potrebné na štúdium, vyhl'adávanie a spracovanie informácií a komunikáciu v medzinárodnom prostredí, kde sa stretajú l'udia s najrôznejším kultúrnym pôvodom. Na takéto štúdium ich treba pripravit' vo výučbovom programe odbornej angličtiny (Camiciottoli Crawford, 2010). Európa nadobúda profil multikultúrnej spoločnosti, čo môže byt' ponímané na jednej strane ako obohacovanie, ale na druhej strane môže viest' ku konfliktom odlišných kultúr. Práve cez prizmu týchto skutočností nadobúda význam interkultúrna kompetencia ako spôsobilost' komunikovat' a konat' v interkultúrnych situáciách tak, aby došlo k dorozumeniu účastníkov interakcie bez narušenia ich integrity. Táto sa prejavuje určitým sumárom kultúrnych vedomostí (kognitívna zložka), pochopením, porozumením iných kultúrnych vzorcov a určitou empatiou voči nim (afektívna zložka) a v konaní a správaní zohl'adňujúcom kultúrne rozdiely a špecifiká jednotlivých kultúr (činnostná zložka). Tento triangulačný rámec vyplýva z pedagogických požiadaviek na rozvoj osobnosti študenta vo výchovno-vzdelávacom procese.

Medzinárodné a medzikultúrne prepojenie profesijných a akademických oblastí je v súčasnosti najdôležitejším faktorom ovplyvňujúcim výučbu odborných cudzích jazykov. V popredí didaktiky cudzích jazykov je akademické zameranie a budovanie interkultúrnej kompetencie. Toto smerovanie výučby sa posilnilo najmä po prijatí Bolonskej deklarácie (1999) a adaptovaním jej zásad do vysokoškolského zákona na Slovensku (2002), t. j. začatím Bolonského procesu, ktorý umožnil internacionalizáciu vysokoškolského vzdelávania v Európe. Pre pochopenie nutných zmien v zameraní výučby odborných cudzích jazykov na nefilologických fakultách môžeme súčasné štádium vidiet' ako kontinuum vývojových štádií pred rokom 1990, po roku 1990 a od roku 2002. Tieto zmeny ilustrujeme na príklade odbornej angličtiny v ekonomických vedných disciplínach nasledovne:

\begin{tabular}{|c|c|c|c|}
\hline Indikátor & Pred rokom 1990 & Po roku 1990 & Od roku 2002 \\
\hline $\begin{array}{l}\text { Vstupná } \\
\text { úroveň } \\
\text { vedomostí }\end{array}$ & $\begin{array}{l}\text { začiatočníci až mierne } \\
\text { pokročilí }\end{array}$ & mierne pokročilí & $\begin{array}{l}\text { mierne pokročilí až } \\
\text { pokročilí (B1, B2, C1), } \\
\text { nie začiatočníci }\end{array}$ \\
\hline Ciele & $\begin{array}{l}\text { čítat' a prekladat' } \\
\text { odborné texty; ovládat' } \\
\text { slovnú zásobu }\end{array}$ & $\begin{array}{l}\text { komunikovat' } \\
\text { s odborníkmi }\end{array}$ & $\begin{array}{l}\text { komunikovat' } \\
\mathrm{s} \text { odborníkmi } \\
\mathrm{v} \text { interkultúrnom } \\
\text { prostredí }\end{array}$ \\
\hline $\begin{array}{l}\text { Zameranie, } \\
\text { obsah }\end{array}$ & $\begin{array}{l}\text { výučba všeobecnej } \\
\text { angličtiny s malým } \\
\text { dôrazom na odborný } \\
\text { cudzí jazyk } \\
\text { a komunikáciu; } \\
\text { faktografické štúdium } \\
\text { tzv. reálií danej } \\
\text { krajiny (USA, Vel'ká } \\
\text { Británia, Kanada, } \\
\text { Austrália); }\end{array}$ & $\begin{array}{l}\text { výučba odbornej } \\
\text { angličtiny (English for } \\
\text { specific purposes); } \\
\text { dôraz na potreby } \\
\text { učiacich sa; } \\
\text { prudký rozvoj výučby } \\
\text { angličtiny v } \\
\text { najrôznejších } \\
\text { ekonomických } \\
\text { odboroch - manažment, } \\
\text { podnikanie, cestovný } \\
\text { ruch, financie a } \\
\text { bankovníctvo, verejná } \\
\text { správa a ekonomika; }\end{array}$ & $\begin{array}{l}\text { výučba anglického } \\
\text { jazyka pre daný odbor, } \\
\text { s dôrazom na študijné } \\
\text { a profesijné potreby; }\end{array}$ \\
\hline
\end{tabular}




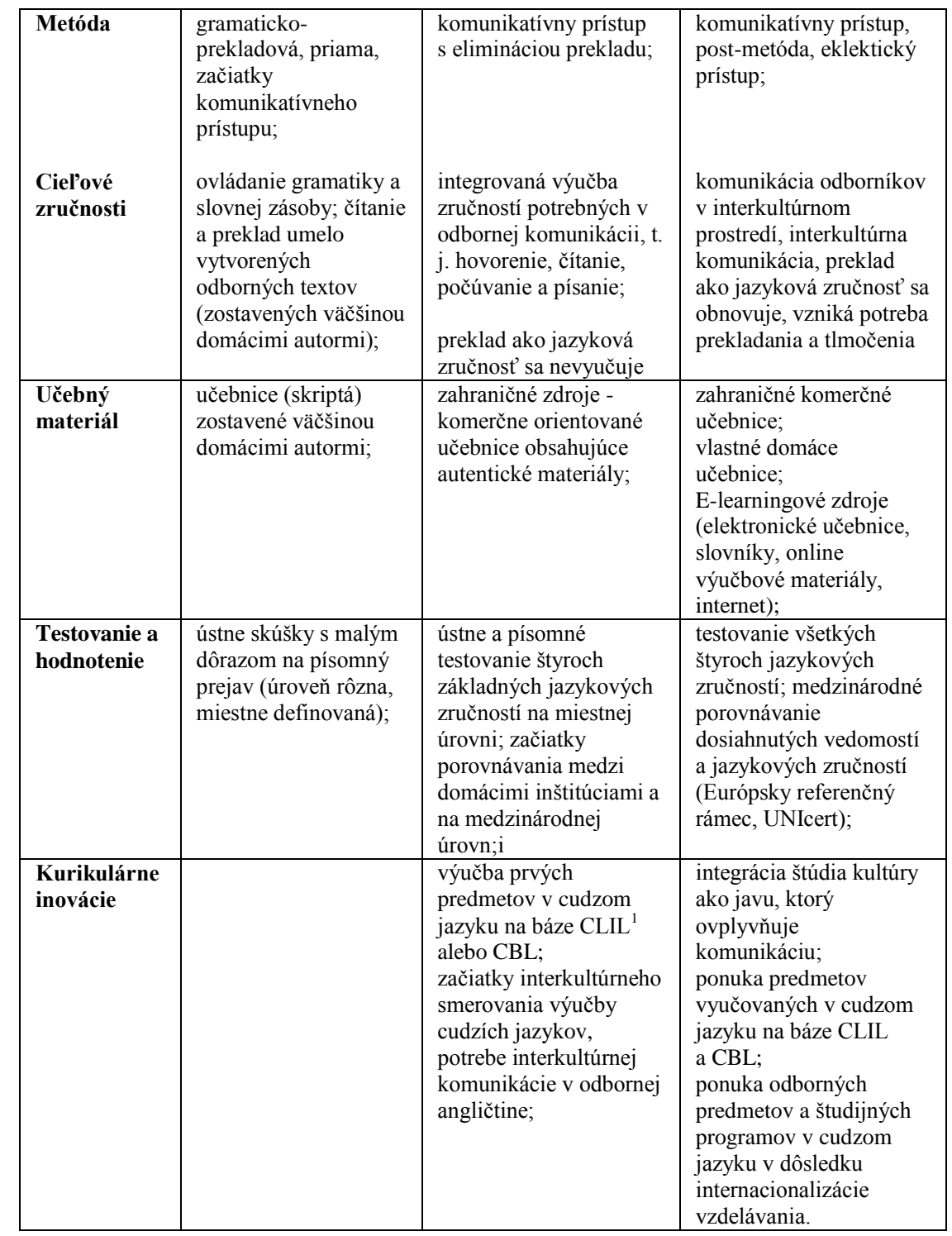

Tabul'ka 1 Indikátory vývoja výučby odbornej angličtiny

Príklady jednotlivých indikátorov ukazujú, že interkultúrny komponent vo výučbe cudzích jazykov je stále viac dôležitý z oboch dôvodov, pre ktorý sa odborný

${ }^{1}$ CLIL sa používa ako skratka pre content and language integrated learning integrované učenie sa cudzieho jazyka a obsahu (odborného predmetu), resp. učenie sa obsahu pomocou cudzieho jazyka; CBL znamená content based learning - učenie sa na báze obsahu; táto skratka sa používa viac v americkej didaktike. 
cudzí jazyk učí: z praktického, profesijného (interkultúrna komunikácia v praxi) a akademického (možnosti štúdia, mobilít $v$ rámci európskych programov). Interkultúrny prístup vo výučbe cudzích jazykov sa dnes pokladá aj za jeden z faktorov rozvíjania viacjazyčnej kompetencie, plurilingvizmu (Birova, 2013, Birova, Bubakova, 2011).

\section{Ciel', obsah a priority odbornej jazykovej prípravy dnes}

Nároky kladené na výučbu odborných cudzích jazykov musia mat' na zreteli všetci zainteresovaní na tomto procese: učitelia, študenti, tvorcovia odborných predmetov a študijných programov s ciel'om vyzbrojit' študenta takými jazykovými vedomost’ami, zručnost'ami a praktickými stratégiami, ktoré mu umožnia spol'ahlivú a z kultúrneho zretel’a efektívnu komunikáciu.

Základný ciel' odbornej jazykovej prípravy nefilológov možno všeobecne stanovit' tak, aby študenti (komunikanti) dosiahli komunikačnú kompetenciu adekvátnu špecifickému sociálnemu kontextu, v ktorom sa pohybujú a komunikujú. $\mathrm{Na}$ začiatku by sa mal klást' dôraz na osvojenie si základných komunikačných kompetencií potrebných na úspešné fungovanie v akademickom (vysokoškolskom) prostredí, t. j. na zvládanie komunikácie $\mathrm{v}$ situáciách, ktoré súvisia s prípravou na povolanie (univerzita, štúdium, mobilita). Simkova (2011: 323) definuje čiastkové kompetencie ako tie, ktoré súvisia so štúdiom a zahŕňajú napríklad štúdium (čítanie) deskriptívnych a explanačných odborných textov, produkciu týchto textov (písanie), spôsobilost' porozumiet' hovorený odborný výklad a ústne sa vyjadrovat' na odborné témy súvisiace so študovaným odborom. Tieto základné komunikačné kompetencie tvoria základ pre d'alšie individuálne alebo inštitucionalizované špecializované jazykové vzdelávanie odborníka (Staskova, 2011: 2). Komunikačná kompetencia predstavuje komplex organicky spojených, vzájomne súvisiacich a podmieňujúcich sa vedomostí, zručností, návykov a schopností umožňujúcich komunikantom zapájat' sa do rečových činností v cudzom jazyku v rozličných komunikačných situáciách (formálnych, neformálnych, oficiálnych i súkromných, bezprostredných či sprostredkovaných). Na jednej strane takáto kompetencia umožňuje získavat' čo najširšiu škálu vecných poznatkov z rôznorodých inojazyčných zdrojov, na druhej strane prezentovat' vlastné odborné znalosti v ústnom i písomnom prejave.

$\mathrm{Na}$ komunikačnú kompetenciu odborníkov by sme mohli aplikovat' definovanie všeobecnej komunikačnej kompetencie (Scarcellova a Oxfordova, 1992: 75-80), ktorá má štyri zložky: a) lingvistickú kompetenciu, čo v podstate predstavuje ovládanie jazykového systému a jazykových prostriedkov typických pre odbornú jazykovú komunikáciu; b) sociolingvistickú, ktorá predstavuje modelovanie rečového správania účastníkov komunikácie, ktorí už disponujú určitým registrom jazykových prostriedkov i schopnost'ou využívat' ich podl'a daného komunikačného kontextu; c) diskurznú - typickú pre danú komunikáciu odborníkov, pre daný odborný štýl a d) strategickú, ktorá predstavuje schopnost' prekonat' nedostatky a t'ažkosti v ktorejkol'vek z uvedených zložiek. Sociolingvistická kompetencia predpokladá poznanie kultúrneho kontextu, v ktorom treba vediet' jazyk správne použit' a predstavuje spôsobilost', ktorú dnes zahrnujeme pod pojem interkultúrnej kompetencie.

Jazykové zručnosti, ktoré má absolvent preukázat', sú už jasne definované v európskom dokumente Spoločný európsky referenčný rámec pre jazyky (Rada Európy, 2001). Tento dokument je nástrojom pre učenie, výučbu a hodnotenie jazykových zručností, stanovuje úrovne ovládania jazyka v zmysle schopností a spôsobilostí. Medzi spôsobilost’ami je zahrnutá aj interkultúrna kompetencia, ktorej náplň by sme mohli ilustrovat' na porovnaní dvoch úrovní ovládania odborného 
cudzieho jazyka, a to B2 (samostatný používatel') a C1 (používatel' s vynikajúcou znalost'ou). Údaje týkajúce sa interkultúrnej kompetencie sú zvýraznené.

\begin{tabular}{|c|c|}
\hline Úroveň B2 (samostatný používatel’ jazyka) & $\begin{array}{l}\text { Úroveň } \begin{array}{c}\text { C1 } \\
\text { s vynikajúcou znalost'ou) }\end{array} \\
\text { s }\end{array}$ \\
\hline $\begin{array}{l}\text { porozumiet' čítaným textom a prednáškam } \\
\text { všeobecného charakteru strednej náročnosti } \\
\text { a jednoduchším textom na tému študijného } \\
\text { zamerania }\end{array}$ & $\begin{array}{l}\text { pochopit' náročný autentický prejav na } \\
\text { všeobecnú tému a tému svojej záujmovej } \\
\text { oblasti, ktorý obsahuje širokú slovnú zásobu }\end{array}$ \\
\hline $\begin{array}{l}\text { sledovat' s porozumením prejav bežnej } \\
\text { a základnej odbornej komunikácie... }\end{array}$ & sledovat’ akademickú prednášku \\
\hline $\begin{array}{l}\text { porozumiet' väčšine televíznych a rozhlasových } \\
\text { spravodajských relácií }\end{array}$ & $\begin{array}{l}\text { zachytit' slovne vyjadrenú alebo nepriamo } \\
\text { vyjadrenú informáciu, aj ked' nie je jasne } \\
\text { štruktúrovaná, porovnat' a usporiadat' } \\
\text { informácie }\end{array}$ \\
\hline $\begin{array}{l}\text { jasne a podrobne opísat' predmety a jazvy } \\
\text { v oblasti svojho záujmu }\end{array}$ & hovorit’ plynule bez väčšieho váhania \\
\hline uviest' argumenty pre a proti & $\begin{array}{l}\text { prezentovat' témy zo svojho študijného } \\
\text { odboru, vystupovat's srezentáciami }\end{array}$ \\
\hline $\begin{array}{l}\text { vyjadrovat' sa dostatočne plynule a spontánne, } \\
\text { aby bola možná bežná komunikácia }\end{array}$ & $\begin{array}{l}\text { vyjadrit’ a zdôvodnit' svoj názor s použitím } \\
\text { zložitých vetných konštrukcií, bohatej } \\
\text { slovnej zásoby.... }\end{array}$ \\
\hline $\begin{array}{l}\text { preukázat' bežné poznatky } \mathrm{z} \text { histórie, } \\
\text { geografie a kultúry krajín ciel'ového jazyka }\end{array}$ & $\begin{array}{l}\text { chápat' kultúrne odlišnosti } \\
\text { Slovenskom a inými krajinami }\end{array}$ \\
\hline $\begin{array}{l}\text { uplatňovat' základy etikety v pracovnej sfére } \\
\text { so zameraním na interkultúrne odlišnosti }\end{array}$ & $\begin{array}{l}\text { primerane } \begin{array}{c}\text { reagovat' } \\
\text { na }\end{array} \text { kultúrne } \\
\text { odlišnosti, dodržiavat' úzus a etiketu }\end{array}$ \\
\hline & $\begin{array}{l}\text { rozlišsovat' štýly pri ústnej a písomnej } \\
\text { komunikácii... }\end{array}$ \\
\hline
\end{tabular}

Tabul'ka 2 Porovnanie úrovni ovládania jazyka B2 a C1 s prihliadnutím na odborný cudzi jazyk (spracované podl'a SERR pre jazyky (2006)).

Rozdiel v požiadavkách na interkultúrnu kompetenciu je značný. Kým na nižšej úrovni ide o základné vedomosti o ciel’ovej kultúre, na vyššej úrovni už ide o vedomosti, pochopenie odlišností a primerané reagovanie v kultúrne a profesijne podmienených situáciách, výber jednotlivých štýlov a ich aplikáciu vinterakcii s cudzincom. Ciel'om odbornej jazykovej prípravy je teda rozvíjat' u študenta také kompetencie (jazykové, socioprofesijné a interkultúrne), ktoré mu umožnia úspešnú komunikáciu vo svojom odbornom kontexte.

Ciele jazykovej prípravy sú špecifické a vyplývajú zo súčasných požiadaviek meniaceho sa akademického i profesijného života. Okrem jasných potrieb vyplývajúcich z praxe, majú na výučbu odborných cudzích jazykov vplyv aj iné faktory. Klasické didaktické trojuholníky (učitel' - žiak - obsah, resp. ciel' - obsah - metóda) je nutné rozšírit' o d’alšie komponenty, ktoré predstavujú a dotvárajú špecifikum didaktiky odbornej angličtiny $\mathrm{v}$ porovnaní so všeobecným cudzím jazykom. Všetky tieto komponenty sa podiel'ajú na úspechu, či neúspechu výučby a osvojenia si odborného cudzieho jazyka a interkultúrnej kompetencie a existujú vo vzájomných súvislostiach. Potreby praxe sa premietajú do výučbových ciel'ov a obsahu, majú vplyv na určenie konkrétnych potrieb konkrétnych učiacich sa, učitel' podl'a nich prispôsobuje obsah a metodiku výučby, táto má vplyv na motiváciu a úspešnost' študentov, rovnako ako prostredie a organizačné podmienky realizácie 
výučby. Tieto faktory ovplyvňujú nielen výber metód a iných výučbových prostriedkov, ale napomáhajú aj učitel'ovi, motivujú ho rovnako ako študenta, majú vplyv na autonómnost' a úspech, ktorý môže byt' medzinárodne porovnávaný a uznávaný a nakoniec nachádza uplatnenie v praxi. Špecifiká odbornej jazykovej prípravy v uvedených didaktických kategóriách možno zhrnút' do uvedenej tabul'ky.

\begin{tabular}{|c|c|}
\hline $\begin{array}{l}\text { Vonkajšie faktory } \\
\text { - potreby praxe }\end{array}$ & $\begin{array}{l}\text { - internacionalizácia vzdelávania } \\
\text { - internacionalizácia pracovného trhu } \\
\text { - interkultúrna komunikácia } \\
\text { - komunikácia odborníkov }\end{array}$ \\
\hline $\begin{array}{l}\text { Výučbový } \\
\text { a učebný ciel' }\end{array}$ & $\begin{array}{l}\text { - efektívna komunikácia v danom odbore } \\
\text { - akademická komunikácia (študijné potreby) } \\
\text { - praktická (profesijná interakcia odborníkov v socio-kultúrnom } \\
\text { kontexte) }\end{array}$ \\
\hline $\begin{array}{l}\text { Učiaci sa/študent } \\
\text { jeho potreby } \\
\text { a ciel'ové } \\
\text { kompetencie }\end{array}$ & $\begin{array}{l}\text { - vysokoškolský - na všetkých stupňoch (pregraduálny, graduálny, } \\
\text { postgraduálny) } \\
\text { - odborník z praxe (vo formálnom, neformálnom, celoživotnom } \\
\text { vzdelávaní) } \\
\text { - neodborník (pre budúce povolanie) }\end{array}$ \\
\hline $\begin{array}{l}\text { Učitel' a jeho } \\
\text { kompetencie }\end{array}$ & $\begin{array}{l}\text { - odborník v jazyku (lingvista) } \\
\text { - odborník v didaktike cudzích jazykov } \\
\text { - odborník v študijnom odbore, pre ktorý jazyk vyučuje } \\
\text { - facilitátor učenia, kouč, radca } \\
\text { - tvorca špeciálnych vzdelávacích programov a učebných materiálov } \\
\text { - prieskumník (realizuje analýzu potrieb učiacich sa) }\end{array}$ \\
\hline Obsah & $\begin{array}{l}\text { - vybrané komponenty z registra odborného cudzieho jazyka } \\
\text { - komunikácia, komunikačné stratégie a zručnosti odborníkov } \\
\text { - odborná lexika, špecifická slovná zásoba } \\
\text { - odborný diskurz a jazykový register } \\
\text { - vedomosti o kultúre a špecifických kultúrach } \\
\text { - interkultúrne vedomosti, zručnosti a stratégie } \\
\text { - interkultúrna komunikácia } \\
\text { - poznatky odboru v cudzom jazyku } \\
\end{array}$ \\
\hline Metodika & $\begin{array}{l}\text { - komunikatívny a eklektický prístup } \\
\text { - integrovanie všetkých jazykových zručností a odbornej slovnej } \\
\text { - zásoby } \\
\text { - interaktívne, aktivizujúce metódy } \\
\text { - kooperatívne učenie } \\
\text { - CLIL/CBLL integrované jazykové a tematické učenie } \\
\text { - podpora autoné na úlohách } \\
\text { - využitie informačiaceho sa } \\
\text { - motivácia: učebnice, odborné časopisy, online zdroje, jazykové } \\
\text { učebne a centrá, návštevy zahraničných prednášajúcich, odborníkov } \\
\text { z praxe; akreditované certifikované cudzojazyčné programy }\end{array}$ \\
\hline $\begin{array}{l}\text { Organizačné } \\
\text { podmienky } \\
\text { (prostredie) }\end{array}$ & $\begin{array}{l}\text { - prístup vedenia fakúlt/univerzít k výučbe a dôležitosti cudzích } \\
\text { - jazykov } \\
\text { - dotácia hodín na výučbu cudzích jazykov } \\
\text { - miesto realizácie výučby } \\
\text { - vel'kost' študijných skupín } \\
\text { - materiálne zabezpečenie a vybavenie (prístup k IT, knižnice, } \\
\text { jazykové centrum, samovzdelávacie centrum, online prístupy, } \\
\text { databázy, knižničné zdroje) }\end{array}$ \\
\hline
\end{tabular}




\begin{tabular}{|l|l|}
\hline & • mobilita študentov \\
\hline Hodnotenie & organizácia odborných stáží v zahraničí \\
\hline & - uplatnenie princípov Spoločného európskeho referenčného rámca \\
& - tvorba testov úroví ovládania jazyka podlidita Rámca reliabilita) \\
& $\begin{array}{l}\text { - možnost' medzinárodného porovnania jazykových výučbových } \\
\text { - možnost' medzinárodného porovnania nadobudnutých jazykových } \\
\text { vedomostí a zručností (skúšky a certifikáty, napríklad UNIcert) }\end{array}$ \\
\hline
\end{tabular}

Tabulka 3 Faktory ovplyvňujúce výučbu odborných cudzích jazykov

Tieto faktory majú vplyv aj na rozvíjanie interkultúrnej kompetencie v rámci výučby odborných cudzích jazykov. Za najdôležitejšie z nich pokladáme:

1. zmenu vzdelávacieho obsahu $\mathrm{v}$ štúdiu odborného cudzieho jazyka, ktorý zohl'adňuje sociokultúrne prostredie v komunikácii (dôraz na interkultúrny komponent jazykového vzdelávania),

2. zavedenie a inováciu obsahu samostatných špecifických predmetov zameraných na interkultúrnu komunikáciu a na interkultúrne vzt’ahy (osvojenie si základných vedomostí o kultúre a špecifikách interkultúrnych vzt’ahov),

3. motiváciu pomocou interaktívnych metód (Zelenkova, 2010) a výučbových prostriedkov, napríklad elektronických zdrojov a multimediálnych učebníc (Petrikova, 2014),

4. mobilitné programy Európskej únie a pracovné stáže, ktoré aj v rámci inštitucionálneho vzdelávania môžu sprostredkovat' osobnú skúsenost' s cudzou kultúrou,

5. medzinárodne porovnatel'né výsledky vzdelávania v cudzích jazykoch umožňujúce uplatnenie v praxi.

\section{Interdisciplinárny charakter výučby odbornej angličtiny a rola učitel’a pri rozvíjaní interkultúrnej kompetencie}

Hutchinson a Waters vo svojej priekopníckej publikácii English for Specific Purposes (1987: 16-19) považujú vyučovanie odbornej angličtiny za prístup k učeniu sa tohto jazyka, nie druh jazyka či špeciálny postup pri vyučovaní. Podl’a nich je odpoved’ou na jednoduchú otázku: Prečo sa tento žiak/študent potrebuje učit' cudzí jazyk? Najdôležitejším faktorom pre návrh kurzu sú teda súčasné i budúce potreby učiacich sa.

Dudley-Evans a St Johnova (1998: 76), Chlopek (2008) a mnohí učitelia anglického odborného jazyka na slovenských a českých vysokých školách (Hanesova, 2007, Sikolova, Kanokova, 2007, Gadusova, Gromova, 2004) sú toho názoru, že odborná angličtina by mala používat' metodiku odlišnú od všeobecnej angličtiny. Mala by vychádzat' $z$ dôvodov, prečo sa študenti tento jazyk učia. Študenti si uvedomujú svoju potrebu učit' sa cudzí odborný jazyk, uvedomujú si ciel'ovú situáciu, ktorou je komunikácia v cudzom jazyku na odbornej úrovni. Používanie cudzieho odborného jazyka tak súvisí s celkom osobitným komunikačným kontextom, ktorý sa podstatne odlišuje od jazyka bežnej komunikačnej sféry. Táto komplexnost' v nazeraní na odbornú angličtinu a interkultúrnu komunikáciu naznačuje jej interdisciplinárny charakter s vplyvom viacerých vedeckých disciplín (Atasaratnam, 2014; Spencer - Oatey, 2009). Interdisciplinárne súvislosti treba brat' do úvahy pri stanovení kompetencií, pri zostavovaní učebných plánov, tvorbe nových predmetov a študijných programov, aj pri príprave učitel'ov, ktorí sa podiel'ajú na formovaní profilu absolventov vysokoškolského štúdia.

Didaktika odbornej angličtiny vyžíva poznatky predovšetkým z lingvistiky, psychológie a pedagogiky, ale premietajú sa do nej aj poznatky z d’alších vied, 
napríklad zo sociológie, sociolingvistiky, antropológie, kulturológie, filozofie, ktoré mali aj v minulosti vplyv na to, ako sa jazyk chápal a ako vyučoval. Lingvistika ovplyvňuje výber relevantných jazykových funkcií a im zodpovedajúcich jazykových prostriedkov. Ide napríklad o výber lexiky (odbornej slovnej zásoby a frazeologických jednotiek, pozri Hou, 2014, Miskova, 2009: 189 - 193, Chorvat, 2003: 179-184, Polcicova, 2007), frekventovaných gramatických javov a typických komunikatívnych situácií. Z toho vyplýva, že odborné jazykové vyučovanie sa nemôže orientovat' na bezduché memorovanie jazykových jednotiek, ale na uvedomelú analýzu a syntézu jazykových prostriedkov vo vzt’ahu ku konkrétnym situáciám. Výsledky lingvistického výskumu sa premietajú do jazykového vyučovania ako tri zásady tematickost', situačnost' a funkčnost'. Psychológia poskytuje didaktike cudzích jazykov poznatky o rečových mechanizmoch, procesoch myslenia, reči, pamäti a interferencie iného jazyka. Poznanie d'alších psychologických kategórií, ako napríklad osobnostných typov študenta a učitel'a, učebných štýlov, stratégií a motivácie v edukačnom procese má rozhodujúci význam pri ul'ahčovaní výučby a osvojovaní si odborného cudzieho jazyka.

Pedagogika definuje celkovú filozofiu výchovy, jej smerovanie, miesto vzdelávajúceho sa človeka v spoločnosti, úlohu učitel'a a prístup $\mathrm{k}$ študentovi. Súčasné humanistické prístupy v edukácii sa prejavujú aj vo vyučovaní odborného cudzieho jazyka tým, že učitel' vo svojej práci využíva metódy umožňujúce objavovanie nových poznatkov, metódy s riešením problému, interkultúrne bádatel'ské metódy pomocou web projektov (Lazar, 2013; Chen - Yang, 2014), projektové vyučovanie, metódy umožňujúce rozvíjat' vzt'ah študenta k sebe samému a jeho sociálne vzt’ahy (dramatické hry, rolové hry, simulácie, tímová práca) a metódy a techniky rozvoja duchovných síl podporujúce mentálnu výkonnost' a psychické zdravie (napríklad relaxačné techniky, meditácia) a oceňuje prínos vedomostí každého člena pri spoločnom hl'adaní riešenia problémov (kooperatívne metódy). Pedagogika udáva smer aj pre uplatnenie inovatívnych prístupov, napríklad konštruktivizmu (pozri Liu - Zhang, 2014).

Sociológia pomáha učitel'ovi porozumiet' sociálnym vzt'ahom všeobecne v rámci celej spoločnosti. Tieto sa premietajú do vzt’ahov na vyučovaní, napríklad do mikroklímy v škole, triede, v skupine na seminári, do vzt’ahov medzi študentmi navzájom, medzi učitel'om a študentom a ich vzt’ahu k vonkajšiemu svetu. Od týchto vzt’ahov sa odvodzujú interaktívne komunikatívne situácie, ktoré má študent pre svoje potreby v praxi zvládnut'.

Sociolingvistika sa zaoberá vplyvom rôznych aspektov spoločnosti na jazyk. Ide napríklad o kultúrne normy, očakávania a kontext, v ktorom sa jazyk používa. Cudzí jazyk sa študuje ako jazyk v určitom sociálnom kontexte aj v jeho variabilnosti. Študent odbornej angličtiny má byt' schopný odlíšit' jazyk v neutrálnom kontexte od jazyka odborníkov, ekonómov, či hovorového a slangového jazyka. Musí byt' vedený $\mathrm{k}$ tomu, aby rozlišoval drobné nuansy sociolektov, pretože len takto môže byt' jeho komunikácia úspešná. Iný výber jazykových prostriedkov si vyžiada komunikácia s ostatnými členmi zamestnaneckého tímu, iný komunikácia s klientom, a iný, ked' klientom bude prominentná osoba, kde treba napríklad dodržat' konvencie diplomatického protokolu (Chorvát, 2006).

Ako sme uviedli na inom mieste, zameranie na sociokultúrny kontext kladie aj $\mathrm{v}$ didaktike cudzích jazykov do popredia otázky vzt'ahu kultúry a jazyka a jeho premietnutie do výučby cudzích jazykov (Javorcikova - Dove, 2013: 11-17). Výučba kultúry vychádza z poznatkov antropológie a kulturológie, ktoré definujú kultúru ako súbor aktivít, hodnôt, presvedčení a vzorcov naučeného správania, ktoré sú charakteristické pre istú skupinu l'udí. Vzorce správania predstavujú aj komunikáciu medzi jednotlivými členmi danej society, používanie jazyka či neverbálnej 
komunikácie. L'udia hovoriaci tým istým jazykom majú spoločné vnímanie reality, ktorá sa odráža v slovnej zásobe a lingvistických štruktúrach jazyka.

V odbornej angličtine sú študenti pripravovaní na komunikáciu s príslušníkmi najrôznejších kultúr v rámci medzinárodných obchodných kontaktov, projektov či výmeny pracovníkov. Pri komunikácii so zahraničnými partnermi budú pravdepodobne najčastejšie používat' angličtinu, a to nielen pri komunikácii s príslušníkmi anglofónnych krajín. Či už budú komunikovat' $\mathrm{s}$ fínskymi alebo japonskými turistami, arabskými, alebo dokonca aj s ruskými a ukrajinskými partnermi, môže byt' ich dorozumievacím jazykom angličtina. Musia si byt' vedomí toho, že mnohokrát dochádza k nedorozumeniam (ktoré môžu viest' aj k zlyhaniu spolupráce alebo kontraktu), a to nie z dôvodu neovládania jazyka, ale, ako sa často ukazuje, z dôvodu nepochopenia rôznych prvkov napríklad neverbálnej komunikácie, alebo rôznych jazykových špecifík vyplývajúcich z iného kultúrneho zázemia. Bez pochopenia kultúry (kultúr) danej jazykovej oblasti nemožno komunikovat' efektívne a spol'ahlivo. V tomto kontexte teda osvojená interkultúrna kompetencia alebo jej nedostatok môžu rozhodovat' o úspechu a efektívnosti resp. neúspechu a neefektívnosti interkultúrnych vzt'ahov. K takejto schopnosti treba vediet', ovládat' určité všeobecné informácie o kultúre ako determinanta l'udského správania, čo môže viest' $\mathrm{k}$ pochopeniu iných kultúr, schopnosti viest' dialóg, $\mathrm{k}$ akceptovaniu rôznorodosti, prekonávaniu stereotypov, predsudkov a vypestovaniu tolerantnosti k odlišnostiam. Základy pre tieto poznatky možno čerpat' z kulturológie, ako d’alšej disciplíny dotvárajúcej poznatkovú bázu pre výučbu interkultúrnej kompetencie $\mathrm{v}$ rámci odbornej cudzojazyčnej prípravy na vysokých školách.

\section{Záver}

Výučba odborných cudzích jazykov a ich osvojovanie predstavujú v súčasnosti dynamicky sa rozvíjajúcu didaktickú disciplínu, ktorá kladie dôraz na rozvíjanie kultúrnej dimenzie s ciel'om rozvíjania interkultúrnej kompetencie a akademických zručností. Využíva poznatky z uvedených vedných disciplín, ktoré sú zakomponované priamo do učebníc vo forme úloh na rozvíjanie kultúrneho povedomia, napríklad na porovnávanie interkultúrnych rozdielov, hladanie spoločných čŕt, riešenie interkultúrnych problémov a nedorozumení pomocou prípadových štúdií, kritických incidentov, individuálnych alebo skupinových projektov a interkultúrnych webových projektov. Príklady vplyvu iných vedných disciplín dokazujú, aká náročná je táto úloha pre učitel’ov odborných cudzích jazykov pre sprostredkovanie interkultúrnej kompetencie. Im už nestačí klasické lingvistickopedagogické vzdelanie, ich profil musia dopíňat' znalosti z týchto vedných disciplín. Sme presvedčení, že ich odborná príprava, či d'alšie vzdelávanie by mali mat' interdisciplinárny charakter. $\mathrm{O}$ to viac, že v poslednom desat'ročí zabezpečujú učitelia cudzích jazykov okrem základnej jazykovej prípravy študentov aj vedenie predmetov na báze CLIL/CBL a svojou odbornost’ou predstavujú hodnotu v celkovej cudzojazyčnej profilácii každej fakulty či univerzity, ktorá chce uspiet' na medzinárodnom edukačnom poli. Akademické a interkultúrne zručnosti, ktoré si študenti osvojujú v cudzojazyčných predmetoch, sa stávajú pridanou hodnotou v profile absolventa, sú uplatnitel'né v štúdiu iných predmetov a v praktických životných situáciách.

\section{References}

ACHUGAR, M. - CARPENTER, B. D. 2014. Tracking movement toward academic language in multilingual classrooms. In: Journal of English for Academic Purposes, vol. 14, pp. 60-71. ISSN 1475-1585 
ARASARATNAM, L.A. 2014. Ten years of research in intercultural communication competence (2003 - 2013): A retrospective. In: Journal of Intercultural Communication, Issue 35, July 2014. ISSN 1404-1634

BIROVA, J. 2013. About Theoretical Definitions of Pluralistic and Pluricultural Approaches. In: XLinguae, European Scientific Language Journal, vol 6, issue 2, 2013, pp. 91-103. ISSN 1337-8384

BIROVA, J. - BUBAKOVA, J. 2011. Multikultura, plurilingvizmus a preklad Charty plurilingvizmu. In: IXLinguae: Trimestrial European Review, vol. 3, issue 4, pp. 5158. ISSN 1337-8384

BORDOVSKAIA, N. Research Potential of Students and Special Features of its Realization in the Learning Process.In: International Journal of Pedagogy and Curriculum, vol. 19, issue 3, pp.165-176.

BYRAM, M. - FLEMING, M. 1998. Language Learning in Intercultural Perspective. Cambridge: CUP. ISBN 0-521-62559-9

CAMICIOTTOLI CRAWFORD, B. 2010. Meeting the challenges of European student mobility: Preparing Italian Erasmus students for business lectures in English. In: English for Specific Purposes, vol 29, issue 4, pp. 268-280. ISSN 0889-4906

CIPRIANOVA, E. 2009. Interkulturne aktivity v cudzojazycnom vyucovani. In: XLinguae.eu, vol. 2, issue 2, pp 17-21. ISSN 1337-8384

DONOHUE, J. P. - ERLING, E., J. 2012. Investigating the relationship between the use of English for academic purposes and academic attainment. In: Journal of English for Academic Purposes, vol. 11, issue 3, pp. 210- 219. ISSN 1475-1585

DUDLEY-EVANS, T. - ST JOHN, M. J. 1998. Developments in English for Specific Purposes. A multi-disciplinary approach. Cambridge: CUP. ISBN 0-521-59675-0

EAST, M. 2009. Addressing the intercultural via task-based language teaching: possibility or problem? In: Language and Intercultural Communication, vol. 12, issue 1, pp. 56-73. ISSN 1747-759X

GADUSOVÁ, Z. - GROMOVA, E. 2004. Vyuzivanie alternativnych metod $\mathrm{v}$ interkulturnom vzdelavani. In: Inonarodne sociokulturne fenomeny a cudzojazycne vzdelavanie. Nitra: SPU. ISBN 80-8069-366-8

GIBSON, R. 2000. Intercultural Business Communication. Oxford: OUP. ISBN 0-19442180-5

HANESOVA, D. 2007. Prienik metodickych pristupov v ESP. In: Kompetence v cizich jazycich jako dulezita soucast profilu absolventa vysoke skoly. Brno: Univerzita obrany, pp. 104-115. ISBN 978-80-7231-261-0

HOLLIDAY, A. R. 2009. The role of culture in English language education: key challenges. In: Language and Intercultural Communication, vol. 9, issue 3, pp. 144155. ISSN 1747-759X

HOLLIDAY, A. R. 2005. The struggle to teach English as an international language, Oxford, , UK: Oxford University Press. New York : Oxford University Press. ISBN 9780194421843

HOU, H. I. 2014. Teaching specialized vocabulary by integrating a corpus-based approach: Implications for ESP course design at the university level. In: English Language Teaching, vol. 7, issue 5, pp. 26-37. ISSN 1916-4750 (Online)

HUTCHINSON, T. - WATERS, A. 1987. English for Specific Purposes. A learningcentred approach. Cambridge: CUP. ISBN 0-521-31837-8

CHEN, J. J. - YANG, S. C. 2014. Fostering foreign language learning through technology-enhanced intercultural projects. In: Language Learning and Technology, vol. 18 , issue 1,2014 , pp. 57-75. ISSN 1094-3501

CHLOPEK, Z. 2008. The Intercultural Approach to EFL Teaching and Learning. In: English Teaching Forum, vol. 46, Nr. 4, pp. 10-19. ISSN 1559-663X 
CHORVAT, J. 2006. Lingvisticke aspekty komunikacie v cestovnom ruchu. In Acta oeconomica 19. Banska Bystrica: Ekonomicka fakulta UMB, pp. 51-55. ISBN 97880-557-0411-1

JAVORCIKOVA, J. - DOVE, M. E. 2013. Explorations in American Life and Culture. Banska Bystrica: UMB, Fakulta humanitných vied. ISBN 978-80-557-0611-5 JORDAN, R. R. 1997. English for Academic Purposes. Cambridge: CUP. ISBN 0521-55423-3

KACMAROVA, A. 2012. O kulturnom kontexte: niektore specifika slovenskej a americkej kultury In: Jazyk a kultura, vol. 9, [online]. Dostupne na internete [cit. 15.1.2014]: 〈http://www.ff.unipo.sk/jak/rus/9_2012/kacmarova.pdf〉.

KIRKGOZ, Y. 2013. The design and evaluation of the effectiveness of an EAP writing course in higher education: Collaboration between a language expert and subject specialists in a blended learning study. In: Higher Education: Recent Trends, Emerging Issues and Future Outlook. Hauppauge NY : Nova Science Publishers, Inc. ISBN: 978-1-62618-834-1

KOLLAROVA, E. 2013. Hovory o kulturologickom smerovani cudzojazycnej edukacie. Bratislava: Statny pedagogicky ustav v Bratislave. ISBN 978-80-8907058-9 KRAMSCH, C. 1998. Language and Culture. Oxford: Oxford University Press. ISBN 0194372146

LAZAR, I. 2013. EFL learners' intercultural competence development in an international web collaboration project. In: Language Learning Journal, 2014. DOI 10.1080/09571736.2013.869941.

LIU, L. - ZHANG, Y. 2014. The application of constructivism to the teaching of intercultural communication. In: English language Teaching, vol. 7, issue 5, pp. 136141. ISSN 1916-4742

LUSTIG, M. W. - KOESTER, J. 2009. Intercultural Competence: Interpersonal Communication across Cultures. London: Pearsons. ISBN 978-02-0559575-4

MISKOVA, Z. 2009. Some Specifics of Teaching Professional English in Tourism. In Acta linguistica 7 - Language for Specific Purposees and Intercultural Communication. Banska Bystrica: Ekonomicka fakulta UMB, pp.189-193. ISBN 97880-8083-791-4

PETRIKOVA, A. 2014. Multimedia text-book as a means of personality development during the process of teaching the Russian language. IN: XLinguae, vol 7/1, pp. 65-74. ISSN 1337-8384

POLCICOVA, M. 2007. Modely obraznosti v jazyku odbornej komunikacie. Banska Bystrica: Ekonomicka fakulta UMB. ISBN 978-80-8083-510-1

RADA EUROPY. 2001. Spolocny europsky referencny ramec pre jazyky: ucenie sa, vyucovanie a hodnotenie. Bratislava: Statny pedagogicky ustav. ISBN 0-521-00531-0 RIES, L. - KOLLAROVA, E. 2007. Svet cizich jazyku - Svet cudzich jazykov dnes. Inovacne trendy v cudzojazyčnej vyucbe. Bratislava: Didaktis. ISBN 80-89160-11-5

RYCKER, A. G. H. 2014. Mitigation in turning down business proposals across cultures: The case for pragmatic competence instruction. In: 3L: Language, Linguistics and Literature, vol. 20, issue 1, pp. 87-101. ISSN 0128-5157

SCARCELLA, R. C. - OXFORD, R. L. 1992. The Tapestry of Language Learning. Boston: Heinel\&Heinle publishers. ISBN 0-8384-2359-0

SPENCER-OATEY, H. - FRANKLIN, P. 2009. Intercultural Interaction. A Multidisciplinary Approach to Intercultural Communication. Basingstoke/New York: Palgrave Macmillan. ISBN 978-1-4039-8683-6

STASKOVA, J. 2011. Jazykove vzdelavanie na vysokych skolach. In: Klucove kompetencie pre celozivotne vzdelavanie II. Rocenka centra celozivotneho a kompetencného vzdelavania Presovskej univerzity v Presove. Presov: PU, pp. 12-21. ISSN 1338-3388 
SWEENEY-ANDROULAKI, F. et al. 2014. The Acquisition of Subject-specific Vocabulary: A Focus on a Collaborative Dictogloss Task and Teacher Perceptions. In: International Journal of Pedagogy and Curriculum, vol. 20/4, 2014, pp. 1-23. ISSN 2327-9133

SIKOLOVA, M. - KANOKOVA, D. (Eds). 2007. Kompetence v cizich jazycich jako dulezita soucast profilu absolventa vysoké školy. Brno: Univerzita obrany, pp. 235244. ISBN 978-80-7231-261-0

SIMKOVA, S. 2011. Pravnicka anglictina len pre pravnikov? In: Klucove kompetencie pre celozivotne vzdelavanie. Presov: PU, pp. 323-330. ISSN 1338-3388

TANDLICHOVA, E. 2009. Niektore nosne aspekty sucasneho riesenia zamerov novej Koncepcie vyucby cudzich jazykov na ZS a SS. In: Pokrivcakova S. a kol. Cudzie jazyky a kultury v modernej škole. Brno: Masarykova univerzita, pp. 7-28. ISBN 978-80-210-4974-1

TRINDER, R. - HERLES, M. 2013. Students' and teachers' ideals of effective business English teaching. In: ELT Journal, Volume 67/2, pp. 220-229. ISSN 09510893

WARREN, M. 2014. Preparation is everything: Meetings in professional contexts in Hong Kong. In: English for Specific Purposes, vol. 36/1, pp. 12-26. ISSN 0889-4906 ZELENKOVA, A. 2004. Intercultural Issues in English Language Teaching. Banska Bystrica : Metodicko-pedagogicke centrum. ISBN 80-8041-478-5

ZELENKOVA, A. 2007. Intercultural Relations in Business. In: New Directions in Teaching and Learning English for Academic and Professional Purposes. Algiers : University of Algiers, Faculty of Arts and Languages, pp. 145-152. ISSN 1112-7279

ZELENKOVA, A. 2010. Interkulturne vzdelavanie v cudzich jazykoch na vysokej skole : metody a ich reflexia. Banska Bystrica: Ekonomicka fakulta UMB. ISBN 97880-557-0014-4

ZELENKOVA, A. 2010. Key Competencies for Managing Cultural Diversity in Business. In: Management de la diversité culturelle: quels enjeux en Europe? The Management of Cultural Diversity: What are the Stakes in Europe? Côme, T., Mešková, L'. (eds). Bruxelles : Bruylant, pp. 69-77. ISBN 978-2-8027-3560-1

ZELENKOVA, A. - SPISIAKOVA, M. 2009. The Development of ESP: A Case of the Faculty of Economics, MBU. In Acta linguistica 7. Banska Bystrica: Ekonomicka fakulta UMB, pp. 315-320. ISBN 978-80-8083-791-4

Words: 5753

Characters: 43879 (24,55 standard pages)

PhDr. Anna Zelenkova, PhD

Department of Language Communication in Business

Faculty of Economics

Matej Bel University

Tajovskeho 10

97495 Banská Bystrica

Slovakia

anna.zelenkova@umb.sk 